\title{
Effects of Globomycin on the Morphology of Bacteria and the Isolation of Resistant Mutants
}

\author{
Masatoshi InuKaI, Michiko TaKeuchi and Keiko SHIMIzU \\ Fermentation Research Laboratories, Sankyo Co., Ltd., \\ 2-58, 1-chome, Hiromachi, Shinagawa-ku, Tokyo 140, Japan
}

Received September 21, 1983

\begin{abstract}
Globomycin inhibited the incorporation of $\left[{ }^{14} \mathrm{C}\right]$ diaminopimeric acid (Dap) into the cold $5 \%$ TCA insoluble fraction of Escherichia coli $\mathrm{H} 2143$ at higher concentrations than the minimum inhibitory concentration (MIC).

One-sixth or -seventh molecules of the lipoprotein were found per one molecule of $N$-acetyl glucosamine (GlucNAc) or Dap in globomycin-treated cells as compared with one-twelfth or -thirteenth molecules in normal cells. Among globomycin-resistant cells isolated, one-tenth were lipoprotein-less mutants and they showed a slightly swollen form and leaked RNase into the medium. It was interesting that spheroplast formation of the mutants in the presence of the antibiotic was not observed even at a high concentration.
\end{abstract}

The cell envelope of gram-negative bacteria consists of two layers, the outer membrane and the inner membrane. The peptidoglycen, a constituent of the former membrane, is thought to play a major role in maintaining the bacterial morphology and the antibiotics which inhibit the peptidoglycan synthesis, such as penicillins, cephalosporins, cycloserine and fosfomycin, induce spheroplast formation of E. coli cells. ${ }^{1)}$

It is well known that one-third of the Braun's lipoprotein, one of the major outer membrane proteins of $E$. coli, ${ }^{2)}$ is bound to peptidoglycan by covalent bonds between the carbonyl terminal lysine of the lipoprotein and diaminopimeric acid of the peptidoglycan. ${ }^{3,4)}$ The lipoprotein is synthesized as prolipoprotein which has an extra 20 amino acid residues, called the signal peptide, at its amino terminal end. ${ }^{5}$ This signal peptide is cleaved off by a prolipoprotein processing enzyme. Globomycin, which was found to induce spheroplast formation of E. coli cells, ${ }^{6)}$ inhibits this enzyme and thus accumulation of the prolipoprotein occurs inside the cells. ${ }^{7,8)}$

The isolation of a lipoprotein-less mutant of $E$. coli by Hirota et al. indicates that the Braun's lipoprotein is not essential for bac- terial growth. ${ }^{9)}$ But as the mutant was more sensitive to ethylenediaminetetraacetic acid (EDTA) or some antibiotics it should play some roles in stabilizing the bacterial cell surface.

The bactericidal action of globomycin seems to be due to the accumulation of the prolipoprotein because the lipoprotein-less mutant is resistant to the antibiotic ${ }^{10)}$ and also $E$. coli harbouring 1pp-producing plasmids becomes more sensitive to the antibiotic according to the increasing amount of the lipoprotein. ${ }^{11)}$

In this report, we describe that the spheroplast formation induced by globomycin may be the result of the accumulation of the prolipoprotein followed by the inhibition of peptidoglycan synthesis from analysis of globomycin-resistant mutants.

\section{MATERIALS AND METHODS}

Bacterial strains. E. coli B, E. coli NIHJ, E. coli $\mathrm{H} 2143$, E. coli JE5512, E. coli JE5513 and Klebsiella pneumoniae 602 were used in the present study. E. coli $\mathrm{H} 2143$ is a mutant that can neither synthesize diaminopimerate nor convert it to lysine. ${ }^{12)}$ E. coli JE5513 is a lipoprotein-less mutant isolated by Hirota et al from E. coli JE5512. ${ }^{9}$ 
Incorporation of doubly labeled ${ }^{[14 \mathrm{C}]}$ Dap and ${ }^{[3 \mathrm{H}]} \mathrm{Arg}$ into the cold $5 \%$ TCA insoluble fraction of E. coli H2143. Cell of E. coli $\mathrm{H} 2143$ were grown in DYAB medium ${ }^{12)}$ at $37^{\circ} \mathrm{C}$ overnight without shaking. A $0.1 \mathrm{ml}$ aliquot of the culture was transferred into $0.4 \mathrm{ml}$ of $\mathrm{YAB}$ medium $^{12}$ ) in a test tube containing $1 \mu \mathrm{Ci}$ of ${ }^{[14 \mathrm{C}]}$ Dap and $10 \mu \mathrm{Ci}$ of ${ }^{\left[{ }^{[3]} \mathrm{Arg}\right.}$ and the tubes were incubated at $37^{\circ} \mathrm{C}$ with vigorous shaking. The YAB medium used was prewarmed at $37^{\circ} \mathrm{C}$ before incubation. At intervals, $0.1 \mathrm{ml}$ samples of the cell suspension were removed and placed on Whatman $3 \mathrm{MM}$ paper discs. These were immersed in ice-cold 5\% TCA solution for $30 \mathrm{~min}$, and then washed twice with cold $5 \%$ TCA, twice with ethanol and once with ether successively. After drying, the discs were assayed for their radioactivities with a Beckman liquid scintillation counter with a toluene scintillation system.

Amino-acid analysis of peptidoglycan-lipoprotein complex. From a $2,000 \mathrm{ml}$ culture of $E$. coli B grown at $37^{\circ} \mathrm{C}$ for $3 \mathrm{hr}$ in Trypto-soy bouillon medium with or without $5 \mu \mathrm{g} / \mathrm{ml}$ of globomycin, the peptidoglycan fraction was isolated as the hot $4 \%$ sodium dodecyl sulfate (SDS) insoluble fraction as described by Braun and Rehn. ${ }^{14}$ The samples were hydrolyzed in $6 \mathrm{~N} \mathrm{HCl}$ at $110^{\circ} \mathrm{C}$ for $20 \mathrm{hr}$ under reduced pressure. Amino acid analysis was performed with a Hitachi KLA-5 automatic amino acid analyzer.

Morphological observation. Morphological change was observed under a phase contrast microscope (Nihon Kogaku) or a scanning electron microscope (Hitachi).

Isolation of globomycin resistant mutants. $0.1 \mathrm{ml}$ aliquots of an overnight culture of E. coli JE5512 in Trypto-soy bouillon medium were spread over nutrient agar plates containing 50 ot $100 \mu \mathrm{g} / \mathrm{ml}$ of globomycin and incubated at $37^{\circ} \mathrm{C}$ for several days.

Materials. Globomycin was prepared by the method previously described $(6,13)$. [1,7-14C]2,6-diaminopimeric acid $\quad(105.26 \mathrm{mCi} / \mathrm{mmol})$ and $\mathrm{L}-[2,3-3 \mathrm{H}]$ arginine $(28.9 \mathrm{Ci} / \mathrm{mmol})$ were purchased from New England Nuclear Corp.

\section{RESULTS}

Effect of globomycin on bacterial morphology

When cells of $E$. coli $\mathrm{B}^{6)}$ or $E$. coli NIHJ were grown in Trypto-soy bouillon medium containing 5 or $50 \mu \mathrm{g} / \mathrm{ml}$ of globomycin, respectively, many spheroplast-like and locallylysed cells were seen under the microscope. In Klebsiella pneumoniae, swollen but still long rod-shaped cells with locally-lysed points were seen in the presence of $50 \mu \mathrm{g} / \mathrm{ml}$ of the antibiotic. The viable cell number of $E$. coli $\mathrm{B}$

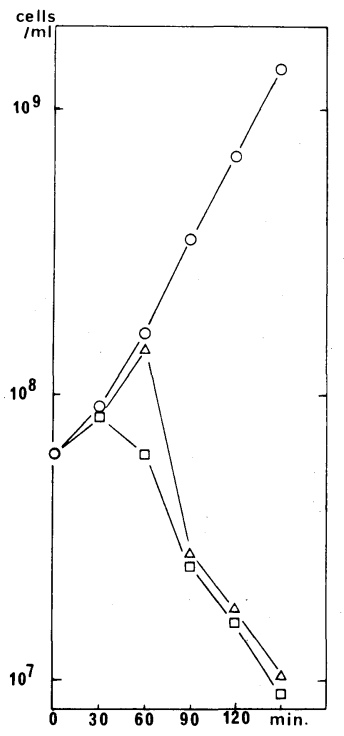

FIG. 1. Bactericidal Activity of Globomycin against $E$. coli $\mathrm{B}$.

Exponentially growing cells were transferred to Tryptosoy broth in the presence or absence of globomycin. Viable cell counts were carried out after dilution with $0.85 \%$ $\mathrm{NaCl}$ or $0.85 \% \mathrm{NaCl}$ containing $8 \%$ sucrose as described in Materials AND Methods. - - -, control; $-\square-$, in the presence of $5 \mu \mathrm{g} / \mathrm{ml}$ of globomycin and diluted with $0.85 \% \mathrm{NaCl} ;-\triangle-$, in the presence of $5 \mu \mathrm{g} / \mathrm{ml}$ of globomycin and diluted with $0.85 \% \mathrm{NaCl}$ containing $8 \%$ sucrose.

rapidly decreased in the presence of $5 \mu \mathrm{g} / \mathrm{ml}$ of globomycin when it was measured after dilution with $0.85 \% \mathrm{NaCl}$ but it was only partially suppressed by the addition of $8 \%$ sucrose in the diluent (Fig. 1). By dilution of globomycin-treated cells with $0.85 \% \mathrm{NaCl}$, almost all of the cells lysed though they maintained their swollen morphology (Fig. 2).

Incorporation of labeled precursors into E. coli H2143

The incorporation of ${ }^{[14 \mathrm{C}]}$ Dap into the cold $5 \%$ TCA insoluble fraction of $E$. coli $\mathrm{H} 2143$ which requires both Lys and Dap for growth was measured as described in Materials AND Methods. Penicillin $G$ and cycloserine inhibited the incorporation of ${ }^{[14 C]}$ Dap more strongly than that of ${ }^{\left[{ }^{3 H}\right]} \mathrm{Arg}$. But chloramphenical inhibited the latter more strongly than the former. In the case of globomycin, 


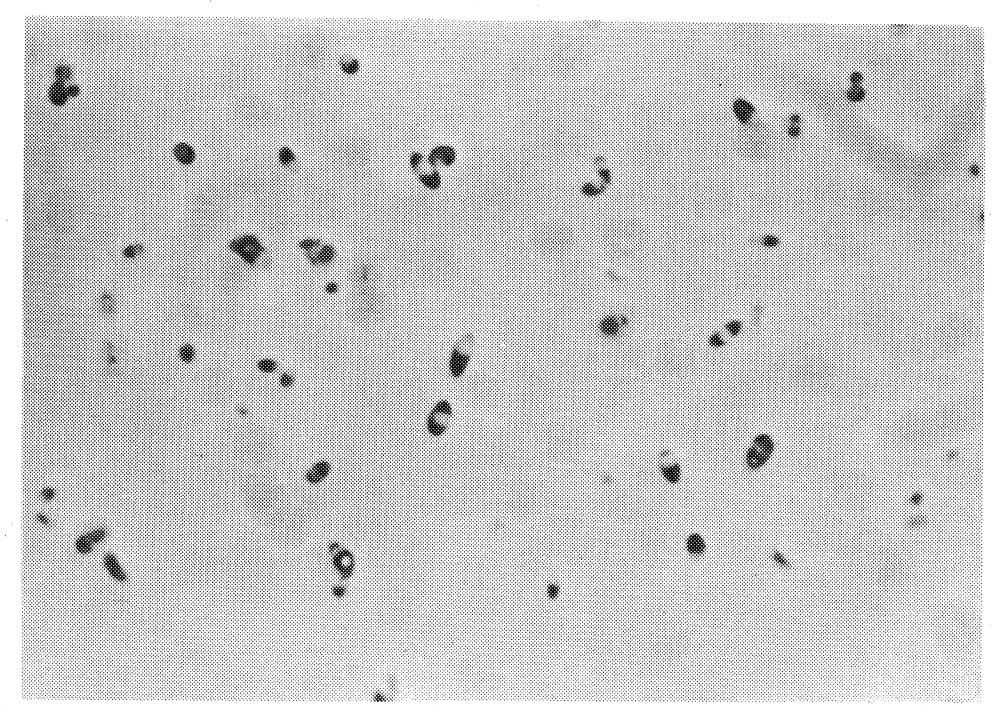

Fig. 2. Phase-contrast Micrograph of E. coli B.

Exponentially growing cells in the presence of $5 \mu \mathrm{g} / \mathrm{ml}$ of globomycin were transferred to $0.85 \% \mathrm{NaCl}$ and a few minutes later the cells were observed under a phase-contrast microscope.

TABLE I. INCORPORATION OF ${ }^{[3 \mathrm{H}]} \mathrm{Arg}$ AND ${ }^{[14 C]}$ Dap INTO COLD 5\% TCA

INSOLUBLE FRACTIONS OF E. coli $\mathrm{H} 2143^{a}$

\begin{tabular}{ccccc}
\hline & \multicolumn{3}{c}{$\begin{array}{c}\text { Incorporation of labeled } \\
\text { precursors }(\% \text { of control })\end{array}$} \\
\cline { 2 - 5 } & \multicolumn{3}{c}{$30 \mathrm{~min}$} & $60 \mathrm{~min}$ \\
& {$[3 \mathrm{H}]$} & {$[14 \mathrm{C}]$} & {$[3 \mathrm{H}]$} & {$[14 \mathrm{C}]$} \\
\hline Globomycin & & & & \\
$10 \mu \mathrm{g} / \mathrm{ml}(\times 1.25 \mathrm{MIC})$ & 89.6 & 100 & 94.2 & 88.0 \\
$50 \mu \mathrm{g} / \mathrm{ml}(\times 6.25 \mathrm{MIC})$ & 89.6 & 75.8 & 75.8 & 59.4 \\
$500 \mu \mathrm{g} / \mathrm{ml}(\times 62.5 \mathrm{MIC})$ & 84.0 & 43.0 & 48.8 & 29.0 \\
Penicillin-G & & & & \\
$10 \mu \mathrm{g} / \mathrm{ml}(\times 12.5 \mathrm{MIC})$ & 96.0 & 44.6 & 65.9 & 20.7 \\
$50 \mu \mathrm{g} / \mathrm{ml}(\times 62.5 \mathrm{MIC})$ & 83.0 & 29.0 & 47.6 & 7.7 \\
Chloramphenicol & & & & \\
$10 \mu \mathrm{g} / \mathrm{ml}(\times 12.5 \mathrm{MIC})$ & 18.7 & 76.5 & 13.0 & 45.8 \\
$50 \mu \mathrm{g} / \mathrm{ml}(\times 62.5 \mathrm{MIC})$ & 15.6 & 70.4 & 8.9 & 44.2 \\
\hline
\end{tabular}

${ }^{a}$ Exponentially growing cells were doubly labeled with ${ }^{[3 \mathrm{H}]} \mathrm{Arg}$ and ${ }^{[14 \mathrm{C}]}$ Dap in the presence or absence of globomycin, penicillin-G or chloramphenicol at the concentrations indicated. At 30 and $60 \mathrm{~min}$ after addition of the drugs, the incorporation of labeled precursors into the cold TCA insoluble fractions was measured.

the incorporation of ${ }^{[14 C]}$ Dap was inhibit-

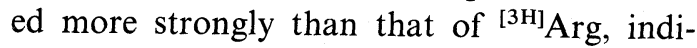
cating the inhibition of peptidoglycan syn-
TABle II. PARTIAL COMPOSITION OF PEPTIDOGLYCAN FRACTION ${ }^{a}$

\begin{tabular}{lcc}
\hline & +globomycin & - globomycin \\
\hline Aspartic acid & 14 & 14 \\
Glucosamine & 6.79 & 11.65 \\
Diaminopimelic acid & 6.35 & 13.03 \\
\hline
\end{tabular}

a Cells of E. coli B were grown in Trypto-soy broth at $37^{\circ} \mathrm{C}$ and $5 \mu \mathrm{g} / \mathrm{ml}$ of globomycin was added at the time when the absorbancy at $550 \mathrm{~nm}$ was 0.40 . After incubation for $3 \mathrm{hr}$ at $37^{\circ} \mathrm{C}$, the cells were harvested and the peptidoglycan fraction was isolated as described in MATERIALS AND Methods.

thesis by the antibiotic (Table I).

\section{Amino-acid analysis of peptidoglycan-lipo- protein complex}

As shown in Table II, an abnormal ratio of lipoprotein to GlcNAc or Dap was found. One mole of lipoprotein (14 aspartic acid residues) was bound per 12 or 13 mol of GlcNAc or Dap in the normal peptidoglycan fraction, but one per 6 or $7 \mathrm{~mol}$ in the same fraction from globomycin treated cells. This result implies that lipoprotein synthesis or attachment is stimulated by globomycin or that peptidoglycan synthesis is inhibited by the antibiotic. 


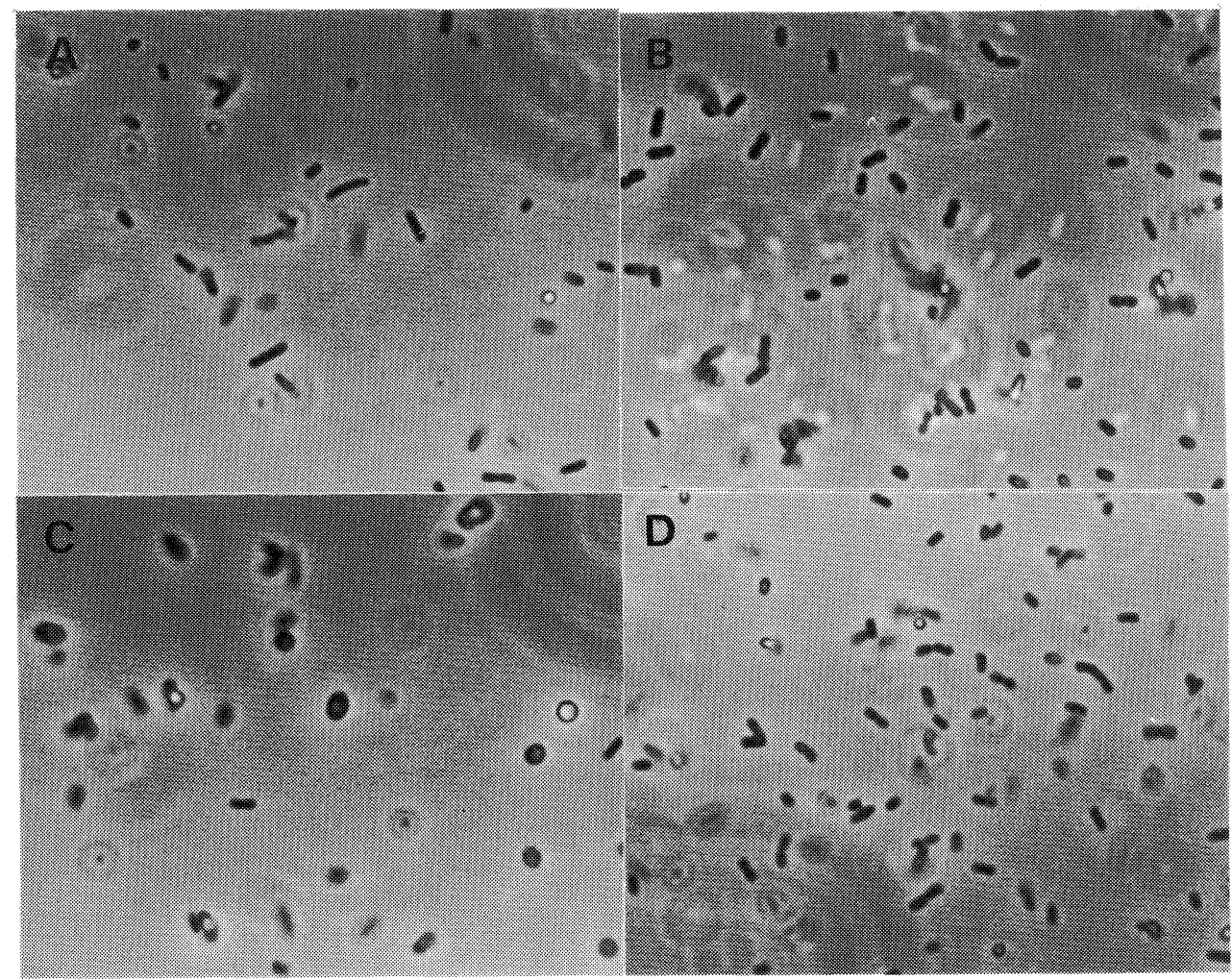

FIG. 3. Phase-contrast Micrographs of the Lipoprotein-less Mutants, E. coli JE5513 and Its Parent Strain, E. coli JE5512.

E. coli JE5512 (A and B) and E. coli JE5513 (C and D) were grown in the presence (B and D) or absence (A and $\mathrm{C}$ ) of $25 \mu \mathrm{g} / \mathrm{ml}$ of globomycin for $5 \mathrm{hr}$ in Trypto-soy broth supplemented with $12.5 \%$ sucrose and $0.1 \%$ $\mathrm{MgSO}_{4}$.

Effects of globomycin on the morphology of lipoprotein-less mutants

The effect of globomycin on the lipoproteinless mutants, especially in regard to the relationship between the resistance and the morphological change of the mutant induced by globomycin, was examined in the present study. Growth inhibition and spheroplast formation of the cells were seen in the parent strain with the same concentration of globomycin, but neither was detected in the mutant strain (Fig. 3). At a higher concentration of globomycin, the growth of the mutant strain was slightly inhibited, but spheroplast formation of the cells was not detected. This mutation is assumed to be a single point mutation as the mutation can be reversed at fairly high frequencies by $\mathrm{P} 1$ phage transduc- tion and these differences between the mutant and parent strains in sensitivity to globomycin seem to be the result of the lipoprotein mutation.

\section{Isolation of globomycin resistant mutants}

To verify the above assumption, several lipoprotein-less mutants were isolated. When nutrient agar plates containing $100 \mu \mathrm{g} / \mathrm{ml}$ of globomycin were used as selective plates and $0.1 \mathrm{ml}$ of an overnight culture was spread on each plate, colonies very rarely grew on the plates. But on using plates containing $50 \mu \mathrm{g} / \mathrm{ml}$ of the antibiotic, many colonies were detected after 2 days' incubation though there were only a few colonies detectable on the overnight culture plates. The mutants from the two days' plates were checked for their resistance to 

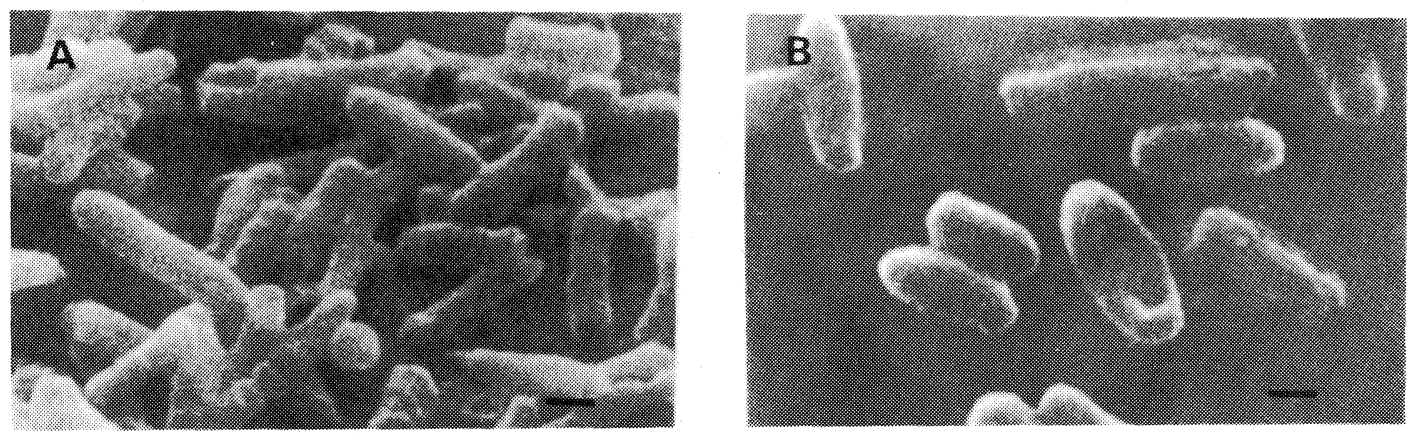

FIG. 4. Scanning Electron Micrographs of Globomycin-resistant Mutants of E. coli JE5512.

A, E. coli GR22; B, E. coli GR26. The bars equal $1 \mu$.

globomycin and stored on nutrient agar slants. We obtained 180 resistant mutants at a frequency of about $10^{-6}$. This is a very high frequency because spontaneous mutation normally takes place at a frequency of about $10^{-8}$ or $10^{-9}$.

\section{Characterization of globomycin-resistant mu- tants}

Since both $E$. coli JE5513 isolated by Hirota et al. ${ }^{9)}$ and the lipoprotein processing deficient mutant, E. coli E614, isolated by Wu et al. ${ }^{14)}$ leaked RNase into the medium and were simultaneously resistant to globomycin, ${ }^{10)}$ each of the 180 isolates was tested as to its RNase leakage according to the method of $\mathrm{Wu}$ et $a l .{ }^{14)}$ Among them, 18 mutants leaked RNase strongly and the rest did not. So the frequency of simultaneous mutations for globomycin resistance and RNase leakage was about $10^{-7}$.

The cell shape of 36 globomycin resistant isolates selected randomyly was observed under a microscope and compared to that of $E$. coli JE5513. As shown in Fig. 4, E. coli GR26 showed a slightly swollen shape similar to $E$. coli JE5513. This morphological change was common to all of the strains showing strong RNase leakage. On the other hand, GR22 did not leak RNase and had a rod shape similar to the wild type strain.

On the addition of globomycin, GR26 showed neither spheroplast formation nor cell lysis even at $400 \mu \mathrm{g} / \mathrm{ml}$ but GR22 did at $100 \mu \mathrm{g} / \mathrm{ml}$ which are the concentrations
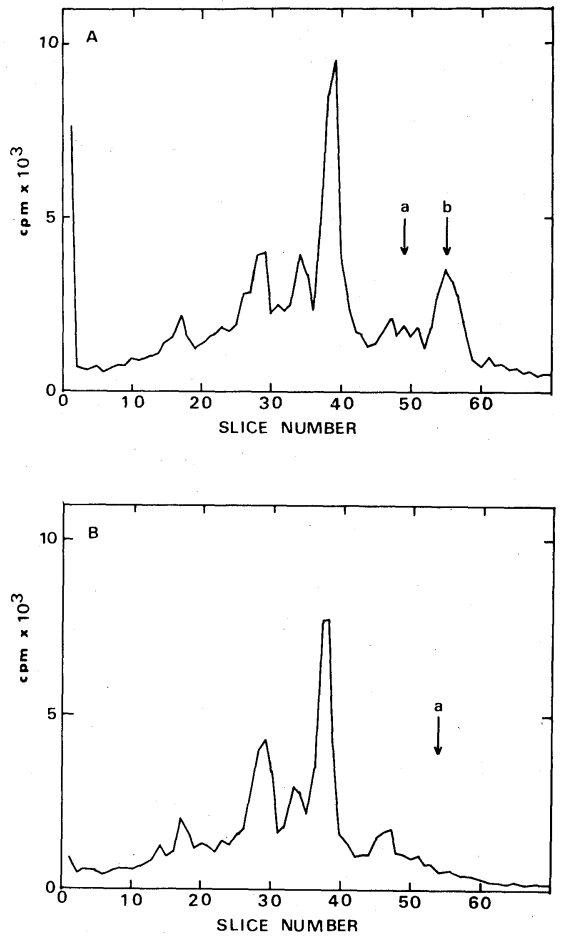

FIG. 5. SDS Polyacrylamide Gel Electrographs of the Envelopes Fractions of E. coli GR22 (A) and E. coli GR26 (B) Labeled with ${ }^{[14 \mathrm{C}]} \mathrm{Arg}$.

Exponentially growing cells were labeled in M9-glucose medium with $10 \mu \mathrm{Ci}$ of ${ }^{[14 \mathrm{C}]} \mathrm{Arg}$. After 60 min incubation at $37^{\circ} \mathrm{C}$, the envelope fraction was isolated by differential centrifugation. The envelope fraction was solubilized in $10 \mathrm{~mm}$ sodium phosphate buffer ( $\mathrm{pH} \mathrm{7.1)}$ containing $10 \%$ glycerol, $1 \%$ SDS, $1 \%$ 2-mercaptoethanol and $0.005 \%$ bromophenol blue at $70^{\circ} \mathrm{C}$ for $20 \mathrm{~min}$. The solubilized envelope fraction was subjected to $7.5 \%$ SDS polyacrylamide gel electrophoresis. a, the position of cytochrome $c$; $b$, the lipoprotein. 
inhibiting the growth of the two strains, respectively.

In the profile of SDS polyacrylamide gel electrophoresis of the envelope fraction (Fig. 5), strain GR26 indicated a deficiency in the lipoprotein but no alteration in the other major envelope proteins. On the contrary, strain GR22 indicated no change in the envelope protein pattern including the lipoprotein.

\section{DISCUSSION}

Globomycin induces spheroplast formation of the cells of gram-negative bacteria. ${ }^{6}$ ) As the rigidity of the cell surface of gram-negative bacteria is maintained mainly by peptidoglycan, ${ }^{1)}$ this effect of globomycin may lead to the assumption that the level of peptidoglycan synthesis decreases in globomycin-treated cells. The incorporation of ${ }^{[14 \mathrm{C}]}$ Dap was not decreased at least until $60 \mathrm{~min}$ after the addition of the antibiotic at the MIC, though it was inhibited specifically at a higher concentration of the antibiotic. But at $3 \mathrm{hr}$ after the addition of globomycin the ratio of peptidoglycan units to the lipoproteins changed from 13 to 6 . As the lipoprotein synthesis was not stimulated by the antibiotic and the ratio of the bound form to the free form of the lipoprotein was also unchanged, ${ }^{7)}$ this result implies that the synthesis of peptidoglycan decreased in the cells treated with globomycin. Inhibition of the peptidoglycan synthesis by globomycin may occur in a very local area, which is enough to kill the cells. Cell lysis occurred in prior to the spheroplast formation at local points and the viable cell number decreased at the same time in the hypotonic medium. Globomycin did not af- fect binding of ${ }^{[14 \mathrm{C}]}$ penicillin to its binding proteins. It is interesting that the ratio of the bound form of the lipoprotein to peptidoglycan in the globomycin-treated cells increased from one-thirteenth to one-sixth. It is also interesting to note that the mutation to lpo and leakage of RNase and the change of morphology can be supposed to be caused by one point mutation. Evidence that the lpo mutants did not form spheroplasts in the presence of globomycin also suggests that the peptidoglycan synthesis is inhibited as the result of the accumulation of the prolipoprotein in the membrane fraction of $E$. coli.

\section{REFERENCES}

1) H. J. Rogers, Ann. N. Y. Acad. Sci., 235, 29 (1974).

2) M. Inouye, "Membrane Biogenesis," ed. by A. Tzagoloff, Plenum Press, New York, 1975, p. 351.

3) B. Braun, Biochim. Biophys. Acta, 415, 335 (1975).

4) B. Braun and K. Lehn, J. Biochem., 10, 426 (1969).

5) S. Inouye, S. Wang, J. Sekizawa, S. Halegoua and M. Inouye, Proc. Natl. Acad. Sci. U.S.A., 74, 1004 (1977).

6) M. Inukai, M. Nakajima, M. Osawa, T. Haneishi and M. Arai, J. Antibiot., 31, 421 (1978).

7) M. Inukai, M. Takeuchi, K. Shimizu and M. Arai, $J$. Bacteriol., 140, 1098 (1979).

8) M. Hussain, S. Ichihara and S. Mizushima, J. Biol. Chem., 255, 3707 (1980).

9) Y. Hirota, H. Suzuki, Y. Hishimura and S. Yasuda, Proc. Natl. Acad. Sci. U.S.A., 74, 1417 (1977).

10) J. Lai, W. Philbrick, S. Hayashi, M. Inukai, M. Arai, Y. Hirota and H. Wu, J. Bacteriol., 145, 657 (1981).

11) M. Inukai, C. Ippolite and $M$. Inouye, in preparation.

12) T. Kamiryo and J. L. Strominger, J. Bacteriol., 117, 568 (1974).

13) M. Inukai, R. Enokita, A. Trikata, M. Nakahara, S. Iwado and M. Arai, J. Antibiot., 31, 410 (1978).

14) D. W. Yen and H. C. Wu, J. Bacteriol., 133, 1419 (1978). 